\title{
Perineural Priscol Injections in Leprosy Ulcers
}

\author{
J. S. MATHUR, M.D., D.P.H., F.R.I.P.H.H. \\ Reader in Social and Preventive Medicine \\ V. N. SEHGAL, M.D., F.R.M.s. \\ Lecturer in Dermato-Venereology \\ N. S. N. RAO, M.sc. \\ Statistician, Department of Social and Preventive Medicine \\ all of the College of Medical Sciences, Banaras Hindu University, Varanasi, India
}

Leprosy patients with open wounds and ulcers are feared, despised and treated as outcasts. New drugs are being tried for the prevention and management of deformities so that these patients may become useful members of society.

Trophic ulcers are quite commonly met with in leprosy patients and are attributed to relative ischemia and loss of sensation triggered by trauma and sepsis. In the management of ulcers local dressings, plaster, physiotherapy and surgery have a limited role to play. In addition very few hospitals in India are undertaking plastic surgery.

Local use of some of the antileprosy drugs has shown some success. Injections of hydnocarpus oil at the base of the trophic ulcers give healing effects (Chatterjee, I955); Saxena and Mathur ( 1963); Mathur and Saxena (1 965) and Mathur (i 965) have shown beneficial effects of Priscol in leprosy deformities and ulcers.

\section{Material and methods}

Twenty-five patients attending the research centre in the Department of Preventive and Social Medicine with ulcers in the hand and foot were selected for perineural Priscol injections. A clinical and laboratory diagnosis of leprosy was made in every case.

All the patients were treated under identical conditions. They pursued their routine work as before. They used ill-fitted shoes or walked barefoot because of poverty. In spite of repeated advice to avoid excessive strain the patients continued to perform the same physical actions. Most of them had to walk several miles to the Centre. No patient was given plaster casts.
Surgical intervention in two patients before Priscol therapy did not improve the ulcers.

Priscol I ml. (25 mgm.) was injected twice a week by the technique of Saxena and Mathur ( I 963) near the ulnar nerve in the case of ulcers of the hand and round the lateral popliteal nerve in patients with ulcers of the foot. All the patients who were not already receiving antileprosy drugs were given I oo mgm. of sulphones for six days in the week. Twenty patients with trophic ulcers on hand and foot after cure are under observation for the last three to 12 months.

The ulcers were classified into two categories, small and big. Ulcers $12 \mathrm{~mm}$. or more in length or breadth, or more than $4 \mathrm{~mm}$. deep were classified as big ulcers and the rest of the ulcers were taken as small ulcers. Ulcers on the hand were generally small and were situated at interphalangeal joints or the terminal phalanx. Big ulcers were found in the region of the sole with prof use foul-smelling discharge. Patients were given acriflavin cotton and bandages to dress the ulcers. They were not given any antibiotics nor DDS. On the injection days the wounds of most of the patients were found undressed and covered with dust. Initial photographs of ulcers and final photographs after healing of ulcers were taken. A fortnightly record of progress of the ulcers was kept.

\section{Observations}

The details of ulcers are given in Table $\mathrm{I}$.

Number of ulcers treated and the results of treatment in each period are depicted in Table 2 .

Perineural Priscol Injections in Leprosy Ulcers

249 
TABLE I

Details of Ulcers, Size and Discharge, and Walking Habits

\begin{tabular}{|c|c|c|c|c|c|c|c|c|}
\hline \multirow[t]{2}{*}{$\begin{array}{l}\text { Location } \\
\text { of Ulcer }\end{array}$} & \multicolumn{4}{|c|}{ Size of ulcer } & \multicolumn{2}{|c|}{ Discharge } & \multicolumn{2}{|c|}{$\begin{array}{l}\text { Walking habit } \\
\text { for foot ulcers }\end{array}$} \\
\hline & $\begin{array}{l}<12 \mathrm{~mm} \\
\text { in length or } \\
\text { breadth } \\
\text { and } \\
<_{4} \mathrm{~mm} \\
\text { in depth }\end{array}$ & $\begin{array}{l}>12 \mathrm{~mm} \\
\text { in length or } \\
\text { breadth } \\
\text { and } \\
<4 \mathrm{~mm} \\
\text { in depth }\end{array}$ & $\begin{array}{c}\text { any length } \\
\text { or breadth } \\
\text { and } \\
>4 \mathrm{~mm} \\
\text { in depth }\end{array}$ & Total & Small & $\begin{array}{l}\text { Profuse } \\
\text { and } \\
\text { foul } \\
\text { smelling }\end{array}$ & Barefoot & $\begin{array}{l}\text { Ill-fitted } \\
\text { Shoes }\end{array}$ \\
\hline $\begin{array}{l}\text { Hand } \\
\text { Foot }\end{array}$ & IO & $\stackrel{2}{-}^{2}$ & $\begin{array}{r}2 \\
\text { II }\end{array}$ & $\begin{array}{l}\text { I } 4 \\
\text { I I }\end{array}$ & I3 & $\begin{array}{l}\text { I } \\
\text { I I }\end{array}$ & - & $\overline{6}$ \\
\hline Total & IO & 2 & I 3 & 25 & I 3 & 12 & 5 & 6 \\
\hline
\end{tabular}

TABI, E 2

Minor and Major Ulcers with Results of Treatment

\begin{tabular}{|c|c|c|c|c|c|c|c|}
\hline \multirow{2}{*}{$\begin{array}{l}\text { Type } \\
\text { of } \\
\text { ulcer }\end{array}$} & \multirow{2}{*}{$\begin{array}{l}\text { No. of } \\
\text { ulcers }\end{array}$} & \multirow[b]{2}{*}{$\begin{array}{l}\text { Duration } \\
\text { of } \\
\text { treatment } \\
\text { in reeeks }\end{array}$} & \multirow[b]{2}{*}{$\begin{array}{c}\text { Number of } \\
\text { ulcers } \\
\text { treated } \\
\text { in each } \\
\text { period }\end{array}$} & \multicolumn{4}{|c|}{ RESULT } \\
\hline & & & & Cured & $\begin{array}{l}\text { Reduced } \\
\text { in size } \\
\text { and dis- } \\
\text { charge }\end{array}$ & $\begin{array}{l}\text { Did not } \\
\text { improve }\end{array}$ & $\begin{array}{l}\text { Increased } \\
\text { in size }\end{array}$ \\
\hline \multirow[t]{4}{*}{ Minor } & $\begin{array}{c}\text { Io } \\
\text { (hand) }\end{array}$ & $I-2$ & IO & 2 & 8 & - & - \\
\hline & & $3-4$ & 8 & 4 & 4 & - & - \\
\hline & & $5-6$ & 4 & 3 & I & - & - \\
\hline & & $7-8$ & I & I & - & - & - \\
\hline \multirow[t]{6}{*}{ Major } & $\begin{array}{c}15 \\
(4 \text { in hand }\end{array}$ & $I-2$ & I 5 & - & I 4 & 1 & - \\
\hline & and $I$ in & $3-4$ & I 5 & 2 & I 2 & 1 & - \\
\hline & foot) & $5^{-6}$ & I3 & 3 & 9 & 1 & - \\
\hline & & $7-8$ & IO & 4 & 5 & - & I \\
\hline & & $9-10$ & 6 & I & 4 & - & I \\
\hline & & $>10$ & 5 & - & 4 & - & I \\
\hline
\end{tabular}

TABLE 3

Shows Duration of Ulcer Cured or Improved and Period of Treatment

\begin{tabular}{|c|c|c|c|c|c|}
\hline \multirow{2}{*}{$\begin{array}{l}\text { Period } \\
\text { of } \\
\text { treatment }\end{array}$} & \multicolumn{4}{|c|}{ DURATION OF ULCER } & \multirow[b]{2}{*}{ Total } \\
\hline & -15 days & 30 days & 3 mon'hs & $>3$ months & \\
\hline 1 weeks & 3 & 4 & I & 一 & 8 \\
\hline 5-8 weeks & I & 6 & I & $3++$ & I I \\
\hline$>8$ weeks & - & - & 2 & $3+++$ & 5 \\
\hline Tolal: & 4 & IO & 4 & 6 & 24 \\
\hline
\end{tabular}

++ one each of 7 months, io months and is months duration.

+++ one of 9 months and two of one year duration.

Note: One ulcer of age above one year did not improve but increased in size.

$25^{\circ}$ Leprosy Review 


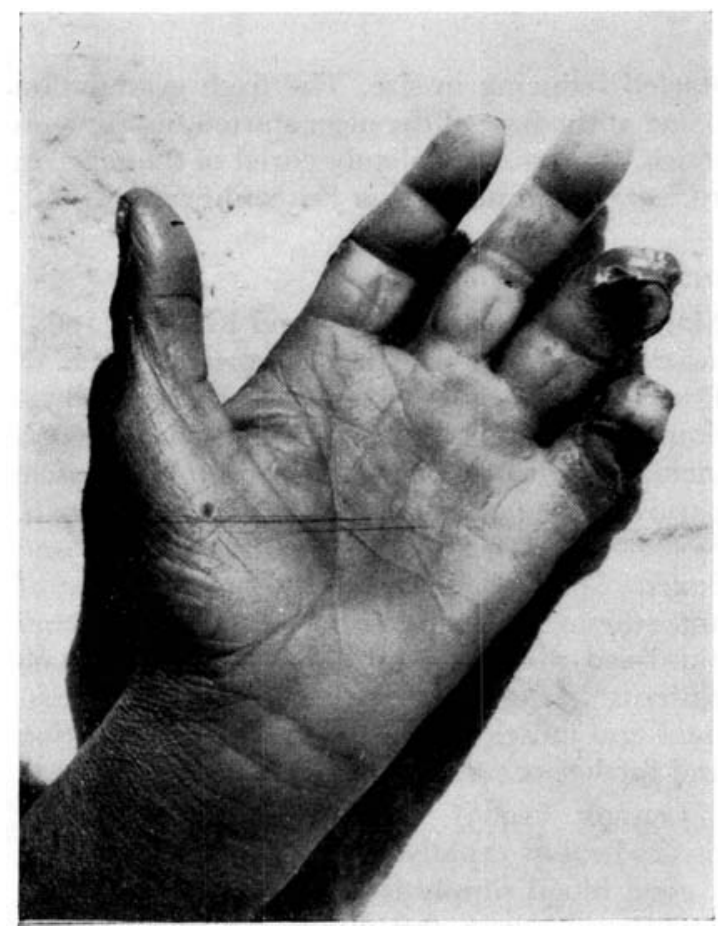

Fir. I

Ulcers on small and ring fingers before Priscol therapy.

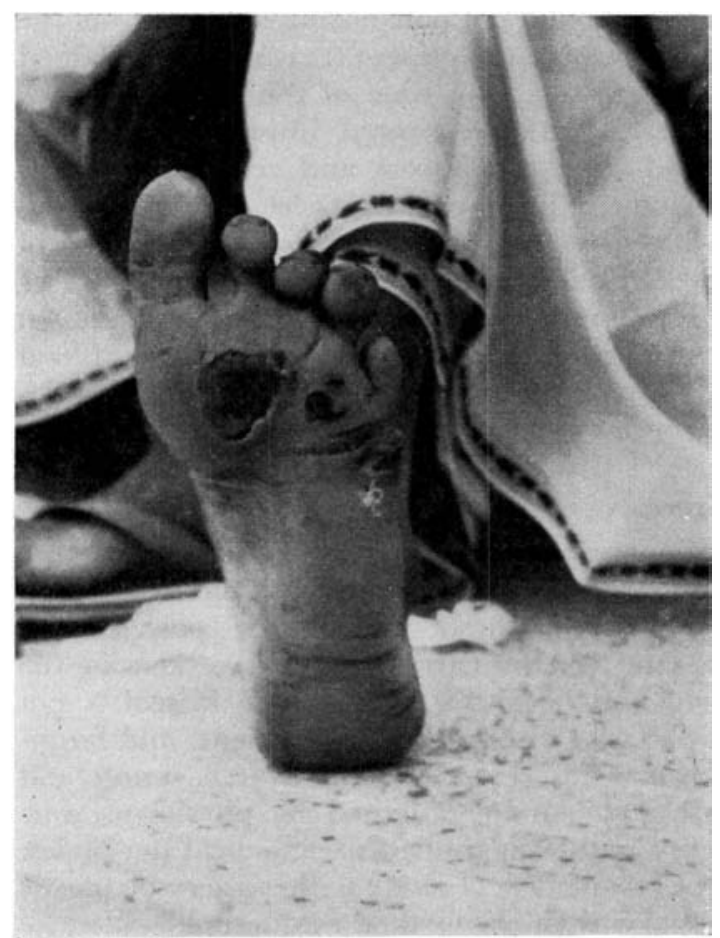

FiG. 3

Trophic ulcers in sole before Priscol therapy.

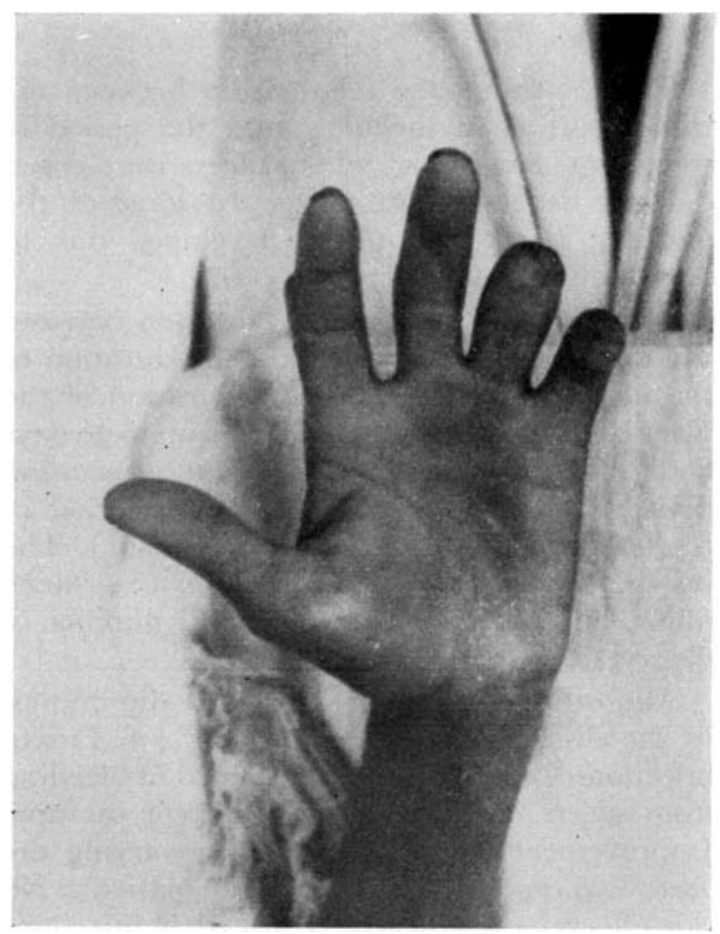

FIG. 2

Healed ulcers on small and ring fingers after Priscol therapy.

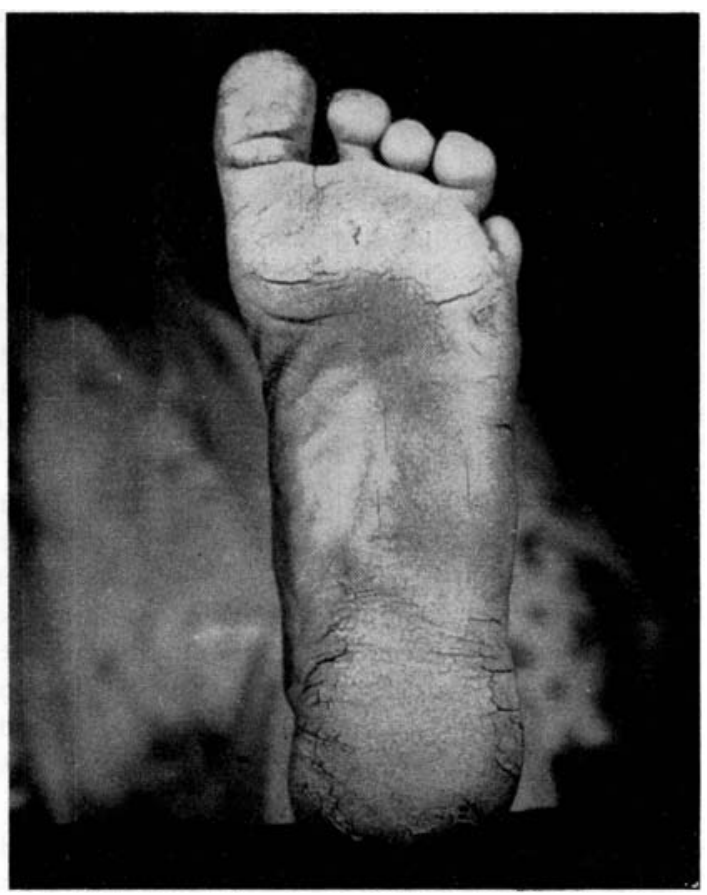

FIG. 4

Healed trophic ulcer in sole after Priscol therapy Perineural Priscol Injections in Ieprosy Ulcers 
Table 3 shows the relationship between the total duration of the ulcer and the period of treatment. Patients in whom ulcers were cured did not develop fresh ulcers. In some of the patients, burns and ulcers developed due to neglect, healed in shorter periods.

There was no significant association between the duration of treatment and the duration of the ulcer. However, when the duration of the ulcer is taken in two groups, that is up to 30 days and above 30 days, a significant association between the duration of ulcer and period of treatment is found $\left(\mathrm{x}^{2}=6 \cdot 404, \mathrm{P} 0 \cdot 05\right)$. The insignificance observed in the first instance might be entirely due to the small number of observations in each cell.

Almost all the patients reported diminution in the discharge from ulcers after 4-6 Priscol injections. Four patients complained of bleeding from ulcers on dressing after Priscol therapy. Improvement in the sensations in varying degrees was reported by most of the patients. No side effects were observed with Priscol injections in any of the cases.

Case i. C. 35 year old male, complained of loss of sensation, deformities of fingers, wasting of muscles of the hand and blisters off and on for the last three years, and an ulcer in the small finger for the last IO-I 2 weeks. (Fig. I). Perineural Priscol injections along the ulnar nerve were given. He was kept on Ioo mgm. of sulphones. He was not given systemic antibiotics. Local dressings of acriflavin were applied. After 7 to 8 Priscol injections the ulcer completely healed (Fig. 2). The patient continued to get Priscol injections. Frequently occurring blisters and swellings of the fingers also subsided and sensations have improved in hand and forearm. $\mathrm{He}$ is under observation for the last three months.

Case 2. N.D., aged 45 years, female, complained of loss of sensation in the hand and deformities and ulcer in the sole for the last three months (Fig. 3). She used leather sandals and walked nearly three miles to reach the Centre. She was given perineural injections of Priscol along the lateral popliteal nerve at the neck of the fibula. She was advised to restrict her walking and was given only acriflavin dressings.

After four injections the foul smelling discharge decreased considerably and the ulcer started reducing in size. The fresh granulation tissue at the base of the ulcer started bleeding on touch. She was completely cured of the ulcer in Io weeks with perineural Priscol injections.

\section{DISCUSS I O N}

Mathur and Saxena (I 963) and Mathur ( I 965) have already shown the beneficial effects of Priscol in leprosy deformities and rehabilitation. Srinavasan (I964) had reported high incidence of trophic ulcers with intrinsic muscle paralysis in feet along with analgesis strain. Saxena and Mathur (1963) and Mathur and Saxena (1965) have shown the improvement of anaesthesia and muscle power in wasted and paralysed muscle of the hand. Priscol in such patients, by restoring to a variable extent sensations and muscle power, helps in the prevention and further occurrence of ulcers.

Lennox (1965) reported that denervated tissues heal as rapidly as normal tissue provided a good blood supply is maintained. Priscol is a vasodilating drug and dilates the blood vessels of nerves and parts supplied by them (Saxena and Mathur, I963). It improves the vascular supply of the ulcerated region. Four of the patients who did not note oozing of blood from the wound before the present treatment complained of bleeding at the time of the dressing of the ulcers. Chatterjee (I955) improved the local blood supply of ulcers and recommended its periodical injection. Crutz et al. (r933) and Goheen ( I 933) were alsle to achieve healing of ulcers by improving vascularity by sympathectomy. Similarly Priscol injections can be given periodically to maintain the improved blood supply of the parts and prevent further occurence of ulcers.

\section{G O N GLUSION}

Priscol provides opportunity both for preventing and curing ulcers by improving the local blood supply, anaesthesia and muscle power. This method can be carried out by workers in the field and hospitals. The cost of Priscol is not prohibitive and most of the patients and hospitals can afford it. The technique is simple and safe and can be practised by physicians, surgeons and even trained paramedical personnel. The use of Priscol along with surgery or plastic surgery requires further evaluation. 


\section{S UMM A R Y}

Twenty-five patients of small and big ulcers were treated with perineural Priscol injections. Smaller ulcers and ulcers of shorter duration healed early. Trophic ulcers in the sole healed with prolonged treatment. All the treated ulcers except one either healed or reduced in size. No fresh ulcers were reported in the regions after healing.

\section{A CKN OWLEDGEMENTS}

The present work could not have materialised without the constant encouragement from Dr K. N. Udupa, Principal, College of Medical Sciences; Dr S. M. Marwah, Professor and Head of the Department of Social and Preventive
Medicine, College of Medical Sciences, Banaras Hindu University, Varanasi; and Dr K. N. Saxena, Professor of Dermatology, S.N. Medical College, Agra.

\section{REFERENCES}

Chatter Jee, s. N. ( I 955) Int. 7. Leprosy, 23, I, I . CRUTZ m. c. AbUel, J. I. (1933), Lep. in India, 5, 5 I and SAMSON, J. G.

GOHEEN, R. N. (I 933), Leprosy in India, 5, 4. LenNox, w. м. ( I 965) Lep. Rev. 36, 3, i og.

mathur, J. s. (1 965), Souv. ioth Annual Conference, A.I.P.H.A. I I 4 .

mathur, J. S. and saxena, K. N. (I965), Lep. Rev. 36, 2, 77.

saxena, к. n. and mathur, J. s. (i 964), J. Ind. Med. Assoc. 42, 3, I 3 I.

SRINIVASAN, H. (1964), Lep. in India, 36, 2, I I O. 